\title{
Representation matters: The impact of descriptive women's representation on the political involvement of women
}

\author{
Bühlmann, Marc ; Schädel, Lisa
}

\begin{abstract}
In a cross-country comparison of 33 European countries, we tested whether a high degree of female representation attenuates the assumed negative impact of gender on political involvement. Our multilevel analyses show positive interactive effects of female representation: the degree to which the representation of women in a given country's national parliament was descriptively adequate was positively related to women's ratings of the importance of politics and self-reported political interest. With respect to political participation, the findings are mixed.
\end{abstract}

DOI: https://doi.org/10.1080/00344893.2012.653246

Posted at the Zurich Open Repository and Archive, University of Zurich

ZORA URL: https://doi.org/10.5167/uzh-61965

Journal Article

Accepted Version

Originally published at:

Bühlmann, Marc; Schädel, Lisa (2012). Representation matters: The impact of descriptive women's representation on the political involvement of women. Representation, 48(1):101-114.

DOI: https://doi.org/10.1080/00344893.2012.653246 


\title{
Representation Matters
}

\section{The Impact of Descriptive Women's Representation on the Political Involvement of Women}

\author{
Marc Bühlmann and Lisa Schädel \\ University of Berne
}

\begin{abstract}
In a cross-country comparison of 33 European countries, we tested whether a high degree of female representation attenuates the assumed negative impact of gender on political involvement. Our multilevel analyses show positive interactive effects of female representation: the degree to which the representation of women in a given country's national parliament was descriptively adequate was positively related to women's ratings of the importance of politics and self-reported political interest. With respect to political participation, the findings are mixed.
\end{abstract}

\section{Introduction ${ }^{1}$}

One of the most widely accepted normative principles of democracy is political equality. According to Dahl $(1989,2006)$, the idea of equal participation rights for all citizens lies at the heart of democracy. However, equal rights themselves do not seem to suffice. The case of women's political representation illustrates that effective gender equality has not yet been achieved. Several decades after the introduction of women's suffrage rights, women are still clearly underrepresented in the vast majority of national parliaments. 
In this article, we argue that low representation of women in national parliaments not only challenges the normative idea of equality in terms of political representation, but also has negative effects on equality of political involvement. This argument leans on the idea of descriptive representation, according to which the composition of a parliament should mirror the heterogeneity of the represented population (Banducci et al. 2004; Burns et al. 2001; Mansbridge 1999; Urbinati and Warren 2008; Young 2002). In our study, we aimed to empirically test one of the fundamental assumptions of this approach in a cross-country comparison - that mirror representation encourages political involvement. More precisely, we analysed the impact of different degrees of women's representation in national parliaments on the effects of gender on political involvement, that is, women's motivation to take part in politics and their effective political participation. Thus, we tackle the question of whether adequate female representation is able to strengthen participative equality by attenuating the gender gap in political involvement.

Using multilevel analyses to model cross-level interactions, we tested whether a high number of female Members of Parliament (MPs) in a national parliament attenuate the suggested negative impact of gender on political involvement. Our analyses were based on the fourth and fifth waves of the World and European Values Surveys. Unlike the rare previous studies that have empirically tested the impact of female representation on political behaviour in a single country (e.g., Atkeson 2003; Atkeson and Carrillo 2007; Norris et al. 2004), the current study conducted a cross-country comparison. In contrast to Wolbrecht and Campbell's (2007) comparative study, we included a large number of younger democracies, which allows us to draw more general conclusions independently of specific cultural and regional contexts.

The remainder of this article is composed of four sections. In Section 1, we elaborate on the ideas of descriptive representation and political involvement. Section 2 describes the method and data. In Section 3, we present the empirical results, and the final section offers our conclusions. 


\section{Descriptive Representation and Political Involvement}

Representation can be regarded as one of the most widely explored and oldest research issues in political science. This is, first and foremost, due to the importance of representation for modern democratic states; nationwide democracy is only possible through political representation (Mill 1861/1958; Dahl 1989: 29; Schumpeter 1942). While elections are seen as the most important institutions for creating connections and correspondence between voters and MPs (Pitkin 1967), there are various normative approaches that specify the desired relationship between representatives and the represented, one of which is the descriptive model of representation (Pitkin 1967; Powell 2004).

According to this model, the composition of any body of representatives should mirror the composition of the represented population in the best way possible, based on criteria such as gender, language, or ethnicity. According to Phillips (1998: 228), the arguments brought forward in favour of women's descriptive representation can be broadly divided into four groups: justice, role model, revitalised democracy, and women's special interests arguments. The justice argument states that it is simply unfair for men to monopolise representation and focuses on patterns of inequality (Phillips, 1998). While definitely of crucial importance from a normative perspective, this argument is not of particular interest for our purposes.

The role model argument asserts that elected women candidates "raise women's selfesteem, encourage others to follow in their footsteps, and dislodge deep-rooted assumptions on what is appropriate to women and men" (Phillips 1998: 228). Female politicians serving as role models to other women signal that politics is an arena open to women, thereby increasing female citizens' sense of political competence (Wolbrecht and Campbell 2007; Burns et al. 2001; Norris et al. 2004). Sawer (2010: 216) calls this the "girls can do anything" effect. A higher number of women in politics might also reflect changing attitudes among both men 
and women concerning the role and place of women in society, making it more culturally acceptable for women to show interest and actively participate in politics (Kittilson 2005). Furthermore, some empirical studies have shown that the mere presence of women candidates and MPs seems to increase women's levels of political engagement (e.g. Bühlmann et al. 2010; Hansen 1997; Sapiro and Conover 1997; Burns et al. 2001; Norris et al. 2004).

The revitalised democracy argument asserts that descriptive representation increases political participation and strengthens the legitimacy of democratic institutions (Dovi 2002: 730). This argument stresses the crucial importance of a well-balanced composition of representative assemblies as part of a wider goal of increasing and enhancing democracy.

Finally, women's special interests arguments focus on the particular interests, perspectives and issues of women that would be overlooked without descriptive representation. It has been shown that women MPs bring up different topics on the political agenda, often concerning issues of special interest to women (Childs and Withey 2004; Swers 2002; Wolbrecht 2002), and contribute different perspectives to policy-making (Cramer Walsh 2002). This may act as a signal to female citizens that women's interests are actually taken into consideration, which in turn, increases women's interest in political issues as well as their propensity to actually participate in politics (Norris et al. 2004: 47). In summary, all these theoretical arguments and some empirical evidence allow us to assume that women in parliament inspire their fellow female citizens to be politically involved.

The concept of political involvement is not new. Verba and Nie (1972) were among the first authors to use the notion of involvement to describe different dimensions of political participation (Judd et al. 1981). Most often, involvement is divided into active and passive components (Black and McGlen 1979; Jennings and Markus 1988). The measures that we use in this study are based on this twofold idea of involvement. The passive dimension encompasses important motivational and psychological attitudes, such as the conviction that politics has a high importance in one's life and general political interest. The active dimension con- 
sists of different participation forms. Here, we focus on electoral participation and one protest form, namely, signing petitions.

Our aim was to test whether women's representation indeed has an effect on the political involvement of women. Thus, we formulated the following hypotheses:

A higher proportion of women in a country's parliament has a positive effect on:

- women's political motivation (i.e. the assessment of the importance of politics and general political interest)

- women's political engagement (i.e. electoral participation and signing of petitions).

We do not suggest that representation of women, per se, fosters motivation and engagement, but we expect an interactive effect of female representation. That is to say, we start from the assumption that women, in general, show less involvement than men but that this effect is attenuated by a high number of female MPs in the national parliament. ${ }^{2}$

Admittedly, gender is not the only important determinant of involvement. Therefore, to test our hypotheses, we controlled for several important individual and contextual determinants of involvement. At the individual level, motivation depends on three different bundles of individual characteristics and attitudes (Bühlmann 2006; Knight and Marsh 2002). First, predispositions and resources, such as age, education, and of course, gender, are seen as basic determinants of involvement (Jennings and Markus 1988; Lazarsfeld et al. 1949). The second bundle can be entitled social capital. Associations, especially political parties and labour unions, are seen as schools of democracy where individuals can learn how politics work (Putnam 2000; Paxton 2002; Campbell 2006). As part of the third bundle, we included individual confidence in parliament as a measure of political support, which has been shown to contribute to political motivation and engagement (Dalton 2004). Additionally, engagement depends on motivation. Thus, assessment of the importance of politics and general political interest 
were considered prerequisites for political engagement (Aarts and Semetko 2003; Bühlmann 2006; Verba et al. 1995) and included in the models for political engagement.

We further controlled for important contextual variables, namely, the age of the given democracy, degree of press freedom, GDP per capita, electoral competition, and population size. We argue that the probability of an individual's involvement depends primarily on the political culture of a country. In established and old democracies with high press freedom, it is easier to be involved in politics. The direction of the impact of wealth on political involvement is less clear and could go in either direction (Blais 2006). A widely used determinant that explains electoral turnout is competition (Jackman 1987; Powell 1986): close races in elections should raise involvement. Additionally, we included the population size as a control variable, as we expected the incentives for political involvement to be higher in countries with larger populations (Dahl and Tufte 1973: 13-14).

\section{Data and Method}

To test our hypotheses about the interactive impact of female representation on women's political involvement, we analysed the effect of the mean proportion of women in a given country's national parliament between 1990 and 2000 (or 1995 and 2005) on women's political involvement in that country at the time of the corresponding World Values Survey (WVS)

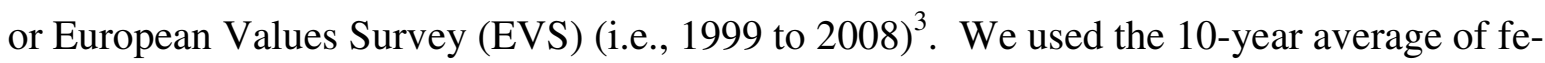
male representation rather than the proportion of women elected during the most recent election because we argue that the political involvement of women develops over time and that political motivation and engagement are matters of long-term socialization ${ }^{4}$.

Before proceeding to the description of our methodology, we would like to draw attention to one obvious problem of our analysis, namely, the problem of causality. We are fully aware of the possibility that the expected relationship (higher representation leads to higher 
involvement) could also operate in the opposite direction. That is, a higher share of politically-involved women in the electorate could lead to more women voted into parliament. We are, however, quite confident that the relationship does indeed operate in the suggested direction and will provide some evidence for this in the final section. Additionally, our macro data, the proportion of female representatives, stems from the years preceding the survey responses. Thus, at the very least, the temporal design complies with the hypothesized relationships.

We included 33 European countries for which 10-year mean proportions of women in parliament are presented in Table 1 . The numbers clearly show that there is no country that demonstrated adequate descriptive gender representation. The highest rate of female representation can be found in Sweden, which had a 10-year mean of $43 \%$, whereas in most other countries in our sample, be they established or younger democracies, the average proportion of women is below $20 \%$.

Table 1: Mean percentages of Women in Lower / Single Chamber of Parliament (1990-2000 or 19952005)

\begin{tabular}{lcc|lcc}
\hline Country & $\begin{array}{c}\text { Women in } \\
\text { Parliament }(\%)\end{array}$ & $\begin{array}{c}\text { Year of } \\
\text { WVS/EVS }\end{array}$ & Country & $\begin{array}{c}\text { Women in } \\
\text { Parliament (\%) }\end{array}$ & $\begin{array}{c}\text { Year of } \\
\text { WVS/EVS }\end{array}$ \\
\hline Sweden & 43.9 & 2006 & Lithuania & 12.1 & 1999 \\
Norway & 37.2 & 2008 & Portugal & 11.9 & 1999 \\
Finland & 35.8 & 2005 & Italy & 11.4 & 2005 \\
Netherlands & 34.7 & 2006 & Ireland & 11.3 & 1999 \\
Denmark & 34.3 & 1999 & Slovenia & 11.0 & 2005 \\
Germany & 30.1 & 2006 & Moldova & 10.8 & 2006 \\
Spain & 27.0 & 2007 & France & 10.6 & 2006 \\
Iceland & 26.1 & 1999 & Russian Federation & 9.2 & 2006 \\
Austria & 23.1 & 1999 & Romania & 9.0 & 2005 \\
Switzerland & 22.2 & 2007 & Albania & 8.1 & 2002 \\
Bulgaria & 19.2 & 2006 & Serbia and Monten. & 7.0 & 2001 \\
Luxembourg & 17.0 & 1999 & Cyprus & 6.4 & 2006 \\
Great Britain & 16.6 & 2006 & Greece & 6.2 & 1999 \\
Poland & 16.3 & 2005 & Ukraine & 6.0 & 2006 \\
Belgium & 12.9 & 1999 & Macedonia & 5.1 & 2001 \\
Bosnia and Herzeg. & 12.9 & 2001 & Turkey & 4.0 & 2007 \\
Czech Republic & 12.3 & 1999 & Overall mean & $\mathbf{1 6 . 0}$ &
\end{tabular}

Source: own calculations based on data from Inter-Parliamentary Union (IPU). 
In our statistical analysis we proceeded in two steps. First, we tested whether gender indeed has a negative impact on women's political involvement -that is, on their assessment of the importance of politics and their general political interest (passive involvement) and on their electoral participation and signing of petitions (active involvement) - and whether this impact varies among the different countries in our sample. If this was not the case, it would preclude a moderating cross-level impact of the different proportions of women MPs on women's political involvement. Presuming there was a variation in the gender effect among countries, in the second step we modelled an interaction of female representation and gender to test whether the presence of a high proportion of women in the national parliament has an attenuating effect on negative gender effects, controlling for the previously discussed individual and contextual determinants of involvement.

Dichotomous dependent variables, namely, electoral participation and signing of petitions, were transformed into a logit structure (see, for example, Long 1997). For a more thorough discussion of the method we used for our multilevel analysis, please refere to the relevant literature (Hox 2010; Jones 1997; Snijders and Bosker 1999; Teachman and Crowder 2002). The operationalization of all variables can be found in the appendix.

\section{Empirical Results}

In Table 2, we tested two models for each involvement measure. The first model is the empty model, from which we can see that both motivation variables varied significantly among the 33 countries in our sample. The variance of the two variables is in large part due to individual characteristics (94 to $95 \%$ ), but at least 5 to $6 \%$ of the variance is due to contextual differences. In the second model we can see that gender has the assumed negative impact on political motivation, that is, women consider politics as less important when compared to men, and they show less interest in politics, in general. 
Table 2: Empty Models and Interactions

\begin{tabular}{|c|c|c|c|c|c|c|c|c|}
\hline FIXED EFFECTS & \multicolumn{2}{|c|}{$\begin{array}{c}\text { Importance of } \\
\text { Politics a) }\end{array}$} & \multicolumn{2}{|c|}{ Political Interest $^{\text {a) }}$} & \multicolumn{2}{|c|}{$\begin{array}{c}\text { Electoral } \\
\text { Participation }\end{array}$} & \multicolumn{2}{|c|}{ Signing Petitions ${ }^{b}$} \\
\hline Constant & $\begin{array}{l}2.21 \\
(.03)^{* *}\end{array}$ & $\begin{array}{l}2.30 \\
(.03)^{* *}\end{array}$ & $\begin{array}{l}2.36 \\
(.04)^{* *}\end{array}$ & $\begin{array}{l}2.53 \\
(.04)^{* *}\end{array}$ & $\begin{array}{c}1.17 \\
(.15)^{* *}\end{array}$ & $\begin{array}{l}1.25 \\
(.15)^{* *}\end{array}$ & $\begin{array}{c}-.52 \\
(.19)^{* *}\end{array}$ & $\begin{array}{c}-.47 \\
(.20)^{*}\end{array}$ \\
\hline $\begin{array}{l}\text { Individual Level } \\
\text { Gender }\end{array}$ & - & $\begin{array}{c}-.18 \\
(.01)^{* *}\end{array}$ & - & $\begin{array}{c}-.31 \\
(.01)^{* *}\end{array}$ & - & $\begin{array}{c}-.15 \\
(.02)^{* *}\end{array}$ & - & $\begin{array}{c}-.09 \\
(.02)^{* *}\end{array}$ \\
\hline $\begin{array}{l}\text { RANDOM EFFECTS } \\
\text { Variance (individuals) } \\
\text { Variance (countries) }\end{array}$ & $\begin{array}{l}.78 * * \\
(.01) \\
.04 * * \\
(.01) \\
\end{array}$ & $\begin{array}{l}.77 * * \\
(.01) \\
.04 * * \\
(.01) \\
\end{array}$ & $\begin{array}{l}.82 * * \\
(.01) \\
.05 * * \\
(.01) \\
\end{array}$ & $\begin{array}{l}.80^{* *} \\
(.01) \\
.05^{* *} \\
(.01) \\
\end{array}$ & $\begin{array}{l}1 * * \\
(0) \\
.77 * * \\
(.21) \\
\end{array}$ & $\begin{array}{l}1 * * \\
(0) \\
.77 * * \\
(.21) \\
\end{array}$ & $\begin{array}{c}1 * * \\
(0) \\
1.25^{* *} \\
(.31) \\
\end{array}$ & $\begin{array}{c}1^{* *} \\
(0) \\
1.25^{* *} \\
(.31) \\
\end{array}$ \\
\hline $\begin{array}{l}\text { MODEL PROPERTIES } \\
\text {-2log likelihood }\end{array}$ & 52752.2 & 52530.5 & 53920.2 & 53307.3 & 21837.7 & 21804.3 & 21974.1 & 21959.8 \\
\hline $\begin{array}{l}\text { Number of cases } \\
\text { (countries) }\end{array}$ & $\begin{array}{c}40^{\prime} 682 \\
(33) \\
\end{array}$ & $\begin{array}{c}40^{\prime} 664 \\
(33) \\
\end{array}$ & $\begin{array}{c}40 ` 804 \\
(33) \\
\end{array}$ & $\begin{array}{c}40^{\prime} 787 \\
(33)\end{array}$ & $\begin{array}{c}39 ’ 716 \\
(33)\end{array}$ & $\begin{array}{c}39^{\prime} 698 \\
(33) \\
\end{array}$ & $\begin{array}{c}39^{\prime} 087 \\
(33) \\
\end{array}$ & $\begin{array}{c}39^{\prime} 071 \\
(33)\end{array}$ \\
\hline
\end{tabular}

Notes: All coefficients are non-standardised coefficients with standard errors in parentheses. All independent variables were rescaled on a scale of $0-1$, where 0 indicates the lowest value and 1 the highest value of the variable. Coefficients, therefore, indicate the change associated with moving from the lowest to the highest value. The Wald test is an approximate $\mathrm{Chi}^{2}$-based test of the fit of the model; * significant at the $90 \%$ level; ** significant at the $99 \%$ level; all models calculated with Stata, a) multilevel mixed-effects linear regression (xtmixed); b) multilevel mixed-effects logistic regression (xtmelogit).

The results for the variables measuring the second dimension of involvement, engagement, are very similar to the findings of the motivation measures. There is, again, considerable contextual variance. Country differences are responsible for $19 \%$ of variation in individual electoral participation and for $28 \%$ of variation in signing of petitions ${ }^{5}$. Again, both participation forms are used significantly more often by men than by women.

In order to test the assumed moderating impact of female representation on women's political involvement, we present several interaction models in Table 3, taking into account individual and contextual factors. As suggested, gender has a significant negative effect on our two motivation variables when there is no female representation (i.e., 0\%). Also, as hypothesised, this reductive effect declines as the proportion of female representatives increases. This can be seen from the significant positive coefficients of the interaction terms in the three models. With respect to our engagement variables, we can find no significant impact of gender, but we again find a strongly significant interaction effect on signing of petitions. 
Table 3: The interactive impact of female representation on motivation and engagement controlled

\begin{tabular}{|c|c|c|c|c|}
\hline & $\begin{array}{c}\text { Importance of } \\
\text { Politics a) }\end{array}$ & Political Interest ${ }^{a)}$ & $\begin{array}{c}\text { Electoral } \\
\text { Participation }\end{array}$ & $\begin{array}{c}\text { Signing } \\
\text { Petitions } b)\end{array}$ \\
\hline $\begin{array}{l}\text { FIXED EFFECTS } \\
\text { Constant } \\
\text { Individual Level } \\
\text { Gender }\end{array}$ & $\begin{array}{l}1.61(.15)^{* *} \\
-.23(.02)^{* *}\end{array}$ & $\begin{array}{l}1.70(.21)^{* *} \\
-.33(.02)^{* *}\end{array}$ & $\begin{array}{r}-1.30(.72)^{*} \\
.11(.07)\end{array}$ & $\begin{array}{c}-1.73(.59)^{*} \\
-.08(.06)\end{array}$ \\
\hline $\begin{array}{l}\text { Age } \\
\text { Education } \\
\text { Member of a party } \\
\text { Member of a labour union } \\
\text { Confidence in parliament } \\
\text { Motivation } \\
\text { Importance } \\
\text { Interest }\end{array}$ & $\begin{array}{l}.50(.02)^{* *} \\
.48(.02)^{* *} \\
.46(.02)^{* *} \\
.05(.01)^{* *} \\
.46(.02)^{* *}\end{array}$ & $\begin{array}{l}.67(.02)^{* *} \\
.67(.01)^{* *} \\
.57(.02)^{* *} \\
.07(.01)^{* *} \\
.43(.02)^{* *}\end{array}$ & $\begin{array}{r}1.81(.07)^{* *} \\
.34(.05)^{* *} \\
.65(.06)^{* *} \\
.35(.04)^{* *} \\
.64(.05)^{* *} \\
.47(.06)^{* *} \\
1.14(.06)^{* *} \\
\end{array}$ & $\begin{array}{r}-.52(.07)^{* *} \\
1.13(.05)^{* *} \\
.32(.05)^{* *} \\
.46(.04)^{* *} \\
-.22(.05)^{* *} \\
.26(.05)^{* *} \\
1.22(.05)^{* *} \\
\end{array}$ \\
\hline $\begin{array}{l}\text { Country Level } \\
\text { Female Representation } \\
\text { Age of democracy } \\
\text { Press freedom } \\
\text { GDP per capita } \\
\text { Competition } \\
\text { Population size }(\log ) \\
\end{array}$ & $\begin{array}{r}-.04(.14) \\
-.06(.17) \\
-.05(.16) \\
.19(.20) \\
-.12(.10) \\
.15(.12) \\
\end{array}$ & $\begin{array}{r}.11(.20) \\
.02(.24) \\
-.15(.22) \\
-.14(.28) \\
.08(.15) \\
-.01(.17) \\
\end{array}$ & $\begin{array}{r}-.08(.73) \\
-1.08(.78) \\
1.26(.77) \\
1.15(.91) \\
.74(.51) \\
-.52(.58) \\
\end{array}$ & $\begin{array}{r}-.85(.59) \\
1.83(.70)^{*} \\
-1.33(.59)^{*} \\
1.18(.75) \\
-.53(.40) \\
.21(.52) \\
\end{array}$ \\
\hline $\begin{array}{l}\text { Interaction } \\
\text { Gender*Representation }\end{array}$ & $.27(.05)^{* *}$ & $.20(.06)^{* *}$ & $-.25(.17)$ & $.49(.14)^{* *}$ \\
\hline $\begin{array}{l}\text { RANDOM EFFECTS } \\
\text { Variance (Individuals) } \\
\text { Variance (Countries) } \\
\text { Slope Variance } \\
\text { Covariance } \\
\end{array}$ & $\begin{array}{l}.71(.01)^{* *} \\
.02(.01) \\
.00(.00) \\
-.00(.00)\end{array}$ & $\begin{array}{l}.70(.01)^{* *} \\
.05(.01) \\
.00(.00) \\
-.00(.00)\end{array}$ & $\begin{array}{l}1(0)^{* *} \\
.63(.19)^{* *} \\
.04(.02)^{*} \\
.11(.06)^{*}\end{array}$ & $\begin{array}{l}1(0)^{* *} \\
.38(.11)^{* *} \\
.02(.01)^{*} \\
-.05(.04) \\
\end{array}$ \\
\hline $\begin{array}{l}\text { MODEL PROPERTIES } \\
\text {-2log likelihood } \\
\text { Number of cases (countries) }\end{array}$ & $\begin{array}{c}47834.761 \\
38^{\prime} 320(33)\end{array}$ & $\begin{array}{r}47678.89 \\
38^{\prime} 424(33) \\
\end{array}$ & $\begin{array}{c}18465.20 \\
36^{\prime} 774(33) \\
\end{array}$ & $\begin{array}{r}19230.28 \\
36^{\prime} 433(33) \\
\end{array}$ \\
\hline
\end{tabular}

Notes: see Table 2

The information provided in Table 3 does not, however, suffice for a satisfactory interpretation of the interaction effects and, therefore, is inadequate for the evaluation of our hypotheses. That is to say, that by simply examining the significance level of the interaction term one cannot determine whether gender has a statistically significant impact on political involvement when the effective proportion of women MPs is greater than zero (Brambor et al. 2006), as is the case in all the countries considered in this study. We, therefore, present graphical evidence in Figure 1, illustrating the marginal effect of being a woman on political involvement across the observed range of female representation. The solid sloping line indicates how the marginal effect of gender changes with the proportion of women in parliament. By considering the $90 \%$ confidence intervals around the line, one can see whether this effect is 
significant: whenever the upper and lower bounds of the confidence interval are both above (or below) zero. ${ }^{6}$

Figure 1: The Marginal Effect of Gender on Political Involvement as Women Representation Changes

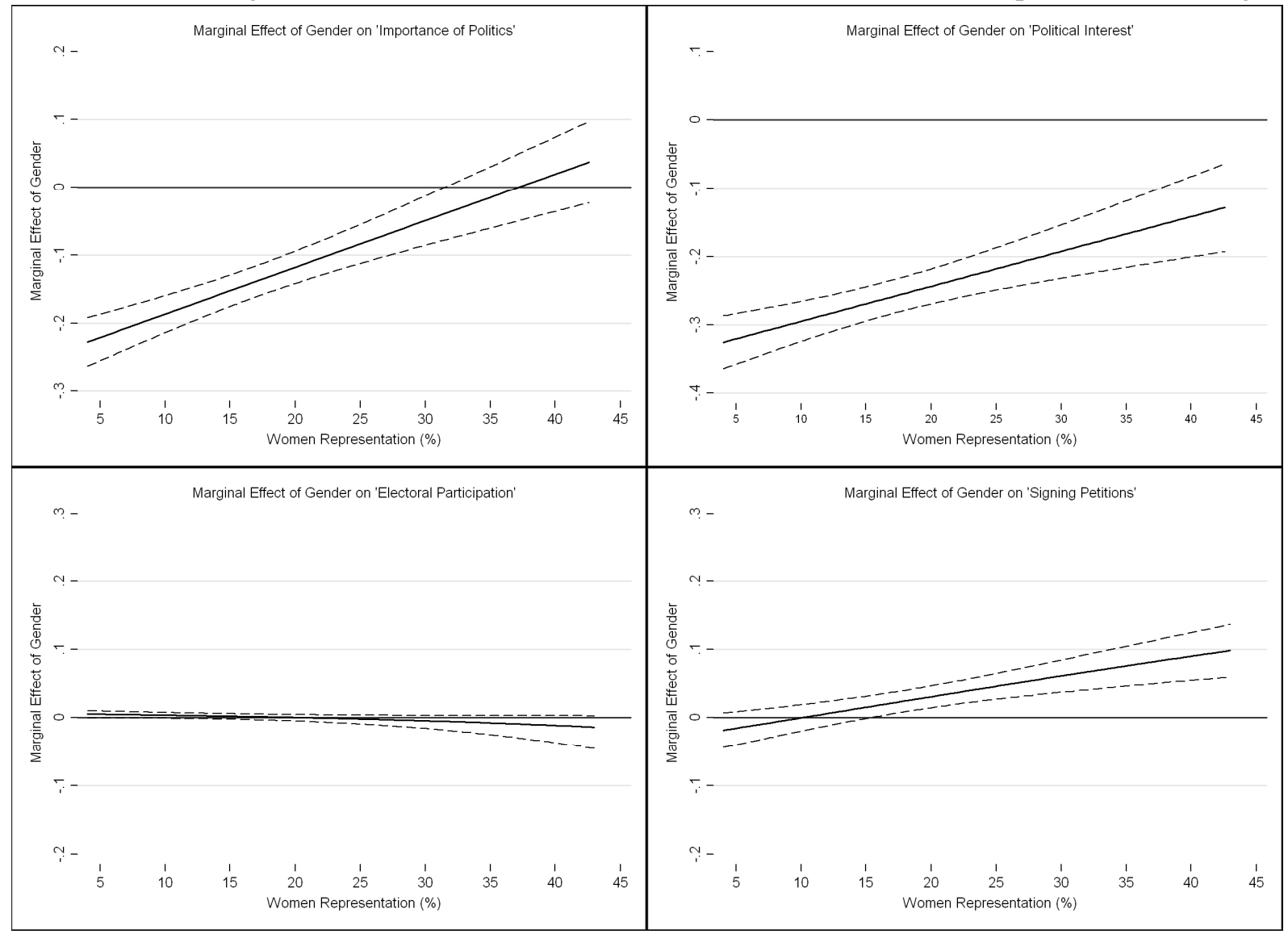

marginal effect of gender

$90 \%$ confidence interval

The figures indicate that female gender has a strong reductive effect on the propensity to find politics important when the proportion of women in parliament is below $32.1 \%$. Above this threshold proportion, the reductive effect of gender is no longer significant. With respect to political interest, gender has a significant reductive effect over the whole spectrum of proportion of female representation. As predicted, the negative effects of gender on both motivation variables decrease substantially with an increase in the proportion of women in parliament, as can be seen from the positive slope of the solid line. Female representation, therefore, has a strong moderating impact. 
On the other hand, gender has no significant effect on electoral participation, no matter how high the proportion of women in parliament. This is contrary to our hypothesis. Finally, the effect of gender on signing petitions is very interesting. From the results in Table 4 we could not make out a significant effect of gender on this form of political participation. Looking at the graphical illustration, we notice that this effect is indeed not significant when women's representation is at its lowest value. However, the effect becomes positively significant at $15.6 \%$ and remains significant over the entire remainder of the range. This result also serves as evidence for the crucial importance of presenting graphical evidence when discussing interaction effects, as by simply looking at the results in Table 3 we would have missed these important results. The fact that the sloping line is above the $\mathrm{x}$-axis means that women actually have a higher propensity to sign petitions once the proportion of women MPs rises above 15.6\%. This higher propensity increases even more with increasing numbers of women MPs.

Summarizing these results on the effect of a higher proportion of women on female citizens' political involvement, we can affirm the following: (a) the negative effect of female gender on women's political motivation is strongly attenuated by a more proportional representation of women in parliament, (b) with respect to the signing of petitions, we also find a positive impact of women's representation, to the extent that women sign petitions even more often than men, given a certain share of women in parliament, ${ }^{7}$ and (c) neither gender nor women's descriptive representation seem to have a significant impact on electoral participation.

As for the individual and the contextual control variables, Table 3 shows some interesting results. First, the motivation variables are the suggested salient prerequisites for engagement. Second, the same holds true for education. Third, involvement generally increases with age; this is not true, however, for the signing of petitions, which decreases among older generations. Fourth, political associations seem to have the assumed educative effect; mem- 
bership in a party or a labour union significantly increases involvement. Fifth, while high confidence in parliament fosters motivation and electoral participation, the probability of signing petitions increases with decreasing confidence. This is a result that seems intuitively comprehensible. The contextual variables do not show the same regular patterns as the individual variables. $^{8}$ The age of democracy and press freedom have significant effects only on the signing of petitions. GDP per capita, high political competition, and population size seem to have no effect on involvement at all.

\section{Discussion}

The aim of this paper was to test whether women's political involvement increases with female political representation. Leaning on the assumptions of the descriptive representation perspective, we argued that increasing female representation in national parliaments fosters political involvement of women. In other words, women become more interested in politics and attribute a higher importance to politics when descriptive representation increases. Additionally, this growing motivation should also increase their political engagement.

We conducted several multilevel models and presented graphical illustrations to show whether there is an influence of different degrees of female representation. Our models confirm that increasing female representation indeed attenuates the negative impact of gender on political motivation. The higher the proportion of women MPs in a national parliament, the smaller is the gender gap concerning the assessment of the importance of politics and general interest in politics. With respect to signing of petitions, we uncovered a positive impact of female gender, once there are a sufficiently high number of female MPs. We, therefore, conclude that, according to the assumptions of descriptive representation, adequate female representation fosters political involvement in women. Female MPs seem to function as role models, inspiring other women to be politically motivated and active themselves. 
Of course, this conclusion must be drawn with caution as at least two critical points can be raised. First, one could object that female representation has no impact on electoral participation, the most important involvement variable of all. Second, it remains unclear whether descriptive female representation leads to political involvement of women or if the relationship works in the opposite direction. Let us briefly discuss these objections. First, it is true that electoral participation is not affected by the share of women in the national parliament. One possible explanation, - the poor measurement of the variable by using the proxy of party preference, - has to be rejected. In other analyses (not presented here) that included only those 18 countries in which the WVS/EVS directly asked about electoral participation, did indeed return a significant effect for gender. However, the effect was positive, meaning that women actually go slightly more often to the polls than men. Furthermore, women's representation has no moderating effect whatsoever. In short, the gender gap with respect to electoral participation seems to be closed in most European countries, which is in line with findings from other research (Conway et al. 2005; Norris 2003). However, our analysis has shown that political motivation is a crucial prerequisite for political participation. Therefore, in order to achieve equal participation rates between women and men, an adequate proportion of women in parliaments seems indispensable.

Finally, as with most research, there is the causality problem. We cannot, of course, completely discard the possibility that the connection operates in the opposite direction from our hypotheses. However, there is some limited evidence that this is not the case. For example, further analyses, not presented here, in which we only examined countries with gender quotas, showed very similar results. We argue that, in these countries, there is a much higher probability of an influence of representation on involvement than the other way around. Of course, more research would be necessary to test not only the problem of causality, but also the impact of different cultures on women's political involvement. Finer-grained analysis 
should further test the socialisation effect of female representation, taking into account the impact of female representation at district or local levels.

We suggest that a $50 \%$ proportion of women in a national parliament would not only be a sign of real gender equality in politics, but also help to improve the quality of democracy. In fact, democratic equality not only means equal representation, but also equal, or genderneutral, involvement. Our results lead us to conclude that this kind of equality at least partly depends on the proportion of women in national parliaments. Thus, two things remain. First, in order to fulfil the normative idea of democratic equality, adequate female representation is an obligation. Second, a high proportion of female MPs in a national parliament seems, at the very least, not to do harm to women's political involvement. 


\section{Appendix}

\begin{tabular}{|c|c|}
\hline Concept & Operationalisation (WVS/EVS variable indicated in squared brackets) \\
\hline Importance of politics & $\begin{array}{l}\text { [a004]: Politics important. For each of the following aspects, indicate how } \\
\text { important it is in your life: Politics. From }(1)=\text { not at all important to }(4)= \\
\text { very important. } \\
\text { All variable numbers indicated in the following refer to the WVS/EVS five } \\
\text { wave aggregated file } 1981-2005 \text {. }\end{array}$ \\
\hline Political interest & $\begin{array}{l}\text { [e023]: Interest in politics: How interested would you say you are in } \\
\text { politics? From }(1)=\text { not at all interested to }(4)=\text { very interested. }\end{array}$ \\
\hline Electoral participation & $\begin{array}{l}\text { [e179]: If there were a national election tomorrow, for which party on this } \\
\text { list would you vote? }(1)=\text { respondent names a party; }(0)=\text { respondent does } \\
\text { not name a party, or no answer or don't know or would not vote or would } \\
\text { cast blank vote or none or null vote; (Missing) = not applicable, not asked } \\
\text { or no right to vote; Variable [e257]: Did you vote in your country's recent } \\
\text { elections to the national parliament? }(1)=\text { yes, }(2)=\text { no. }\end{array}$ \\
\hline $\begin{array}{l}\text { Protest participation } \\
\text { (signing of petitions) }\end{array}$ & $\begin{array}{l}\text { [e025]: Political action: "I'm going to read out some forms of political } \\
\text { action that people can take, and I'd like you to tell me, for each one, } \\
\text { whether you have actually done any of these things, whether you might do } \\
\text { it or would never, under any circumstances, do it." Signing a petition. (1) } \\
=\text { have done; }(0)=\text { might do or would never do. }\end{array}$ \\
\hline Age & $\begin{array}{l}\text { [x003]: Age in years. Variable [x025]: Highest education level attained. } \\
\text { From }(1)=\text { inadequately completed elementary education to }(8)= \\
\text { university with degree. }\end{array}$ \\
\hline $\begin{array}{l}\text { Party / labour union } \\
\text { membership }\end{array}$ & $\begin{array}{l}\text { [a067] and [a068]: Please look at the following list of voluntary } \\
\text { organisations and say...which do you belong to? a) political parties, b) } \\
\text { labour unions. }(1)=\text { yes, }(0)=\text { no. Variables [a101] and [a102]: Now I am } \\
\text { going to read off a list of voluntary organizations; for each one, could you } \\
\text { tell me whether you are an active member }(1) \text {, an inactive member }(1) \text {, or } \\
\text { not a member }(0) \text { of that type of organization? a) labour union, b) political } \\
\text { party. }\end{array}$ \\
\hline Confidence in parliament & $\begin{array}{l}\text { [a069_07]: I am going to name a number of organizations. For each one, } \\
\text { could you tell me how much confidence you have in them: Parliament. } \\
\text { From }(1)=\text { none at all to }(4)=\text { a great deal. }\end{array}$ \\
\hline Age of democracy & Source: Persson and Tabellini (2003). \\
\hline Press freedom & $\begin{array}{l}\text { Taken from Freedom House which measures freedom of the press on a } \\
\text { range from } 0 \text { (free) to } 100 \text { (not free). For our analysis we used the mean } \\
\text { value of } 1995 \text { to } 2000 \text { or } 1995 \text { to } 2005 \text {, depending on the year of the WVS } \\
\text { used in the analysis. }\end{array}$ \\
\hline Wealth & $\begin{array}{l}\text { GDP per capita: mean value } 1990 \text { to } 2000 \text { or } 1995 \text { to } 2005 \text {, source: UN } \\
\text { Data. }\end{array}$ \\
\hline Competition & $\begin{array}{l}\text { Difference between the largest and the second largest lower house party as } \\
\text { a percentage of all seats and subtracted from } 100 \text { (value for } 2000 \text { or 2005); } \\
\text { Source Bühlmann et al. (2011). }\end{array}$ \\
\hline Population size & Source: UN Data \\
\hline
\end{tabular}




\section{NOTES}

1. Our thanks go to Jale Tossun, Didier Ruedin and the other participants of the workshop "Inequality and Representation in Europe" at the Dreiländertagung 2011 in Basel as well as the two anonymous referees for their very helpful comments on a previous version of this article. Parts of this research were led at the Centre for Democracy Research in Aarau and within the NCCR Democracy at the University of Zurich. We thank both institutions for their support.

2. Technically this means that the higher the share of women in the national parliament, the weaker is the effect of gender on political involvement, i.e. the less strong is the (assumed) negative effect of being a woman on: motivation (i.e. the assessment of the importance of politics and political interest) and engagement (i.e. electoral participation and the signing of petitions).

3. In order to have a sufficiently large country sample we use the two most recent WVS/EVS waves. Depending on the year of the most recent survey available for each country, we used the corresponding mean women representation (1990 to 2000 for WVS 4, 1995 to 2005 for WVS 5).

4. We estimated further models (not presented below) with the share of female MPs in the year before the WVS survey as the main independent variable. These have returned almost identical results to the ones presented below.

5. In a logit-model, the share of variance of the individual level accords to 3.29 (Snjiders and Bosker, 1999: 224$)$; the overall variance $(3.29+.77=4.06 ; 3.29+1.25=4.54)$ thus can be attributed to $19 \% / 28 \%$ to the context $(.77 / 4.06 ; 1.25 / 4.54)$ and to $81 \% / 72 \%$ to the individual characteristics.

6. In order for the graphical illustrations to be more easily comprehensible the $\mathrm{x}$-axis is labeled with the non-standardised values of women representation.

7. We also estimated a model for the propensity to join demonstrations and found a significant negative impact of gender up to a women's share of $25 \%$. This effect is also attenuated by a higher women's representation.

8. In several models not presented here, we have introduced the contextual control variables one at a time. The principal results remain the same. 


\section{References}

AARTS, KEES and HOLLI A. SEMETKO. 2003. The divided electorate: Media use and political involvement. Journal of Politics 65(3): 759-84.

ABNEY, F. GLENN and JOHN D. HUTCHESON. 1981. Race, Representation, and Trust: Changes in Attitudes after the Election of a Black Mayor. The Public Opinion Quarterly 45(1): 91-101.

ATKESON, LONNA R. 2003. Not All Cues Are Created Equal: The Conditional Impact of Female Candidates on Political Engagement. The Journal of Politics 65(4): 1040-61.

ATKESON, LONNA R. and NANCY CARRILLO. 2007. More Is Better: The Influence of Collective Female Descriptive Representation on External Efficacy. Politics \& Gender 3(01): 79-101.

BANDUCCI, SUSAN A., TODD DONOVAN and JEFFREY A. KARP. 2004. Minority Representation, Empowerment, and Participation. The Journal of Politics 66(2): 534-56.

BLACK, JEROME H. and NANCY E. MCGLEN. 1979. Male-Female Political Involvement Differentials in Canada, 1965-1974. Canadian Journal of Political Science / Revue canadienne de science politique 12(3): 471-97.

BLAIS, ANDRÉ. 2006. What Affects Voter Turnout? Annual Review of Political Science 9(1): 111-25.

BRAMBOR, THOMAS, WILLIAM ROBERTS CLARK and MATT GOLDER. 2006. Understanding Interaction Models: Improving Empirical Analyses. Political Analysis 14(1): 63-82.

BÜHLMANN, MARC. 2006. Politische Partizipation im kommunalen Kontext - Der Einfluss lokaler Kontexteigenschaften auf individuelles politisches Partizipationsverhalten. Bern, Stuttgart, Wien: Haupt.

BÜHLMANN, MARC, ANTOINETTE FEH WIDMER and LISA SCHÄDEL. 2010. Substantive and Descriptive Representation in Swiss Cantons. Swiss Political Science Review 16(3): 565-95.

BÜHLMANN, MARC, WOLFGANG MERKEL, LISA MÜLLER, HEIKO GIEBLER and BERNHARD WESSELS. 2011. Democracy barometer: Codebook for blueprint dataset version 1. Aarau: Zentrum für Demokratie.

BURNS, NANCY, KAY LEHMAN SCHLOZMAN and SIDNEY VERBA. 2001. The Private Roots of Public Action: Gender, Equality, and Political Participation. Cambridge; Harvard University Press.

CAMPBELL, DAVID E. 2006. Why We Vote: How Schools and Communities Shape our Civic Life. Princeton: Princeton University Press.

CHILDS, SARAH and JULIE WITHEY. 2004. Women Representatives Acting for Women: Sex and the Signing of Early Day Motions in the 1997 British Parliament. Political Studies 52(3): 552-64.

CRAMER WALSH, KATHERINE. 2002. Enlarging Representation: Women Bringing Marginalised Perspectives to Floor Debate in the House of Representatives, in Cindy S. Rosenthal (ed), Women Transforming Congress. Norman: University of Oklahoma Press, pp. 370-96. 
CONWAY, M. MARGARET, GERTRUDE A. STEUERNAGEL and DAVID W. AHERN. 2005. Women and Political Participation. Washington, D.C.: CQ Press.

DAHL, ROBERT A. 1989. Democracy and its Critics. New Haven: Yale University Press. 1998. On Democracy. New Haven: Yale University Press. 2006. On Political Equality. New Haven, CT: Yale University Press.

DAHL, ROBERT and EDWARD TUFTE. 1973. Size and Democracy. Stanford: Stanford University Press.

DALTON, RUSSELL J. 2004. Democratic Challenges, Democratic Choices: The Erosion of Political Support in Advanced Industrial Democracies. New York: Oxford University Press.

DOVI, SUZANNE. 2002. Preferable Descriptive Representatives: Will Just Any Woman, Black or Latino Do? American Political Science Review 96(4): 729-43.

FENNO, RICHARD F. 1978. Home style: House Members in their Districts. Boston: Little, Brown.

GAY, CLAUDINE. 2002. Spirals of Trust? The Effect of Descriptive Representation on the Relationship between Citizens and Their Government. American Journal of Political Science 46(4): 717-32.

HANSEN, SUSAN B. 1997. Talking About Politics: Gender and Contextual Effects on Political Proselytizing. The Journal of Politics 59(1): 73-103.

HOX, JOOP J. 2010. Multilevel analysis: Techniques and applications. London: Routledge.

JACKMAN, ROBERT W. 1987. Political Institutions and Voter Turnout in the Industrial Democracies. The American Political Science Review 81(2): 405-23.

JENNINGS, M. KENT and GREGORY B. MARKUS. 1988. Political Involvement in the Later Years: A Longitudinal Survey. American Journal of Political Science 32(2): 30216.

JONES, KELVYN. 1997. Multilevel Approaches to Modelling Contextuality: From Nuisance to Substance in the Analysis of Voting Behaviour, in G. P. Westert and R. N. Verhoeff (eds), Places and People: Multilevel Modelling in Geographical Research. Utrecht: The Royal Dutch Geographical Society, pp.19-43.

JUDD, CHARLES M., JON A. KROSNICK and MICHAEL A. MILBURN. 1981. Political Involvement and Attitude Structure in the General Public. American Sociological Review 46(5): 660-9.

KITTILSON, MIKI C. 2005. In Support of Gender Quotas: Setting New Standards, Bringing Visible Gains. Politics \& Gender 1(4): 638-45.

KNIGHT, K. and M. MARSH. 2002. Varieties of Election Studies. Electoral Studies 21(2): 169-87.

LAZARSFELD, PAUL F., BERNARD BERELSON and HAZEL GAUDET. 1949. „The People's Choice; How the Voter Makes up His Mind in a Presidential Campaign“. New York: Columbia University Press.

LONG, J. SCOTT. 1997. Regression Models for Categorical and Limited Dependent Variables. Thousand Oaks: Sage.

MANSBRIDGE, JANE. 1999. Should Blacks Represent Blacks and Women Represent Women? A Contingent 'Yes'. Journal of Politics 61(3), 628-57.

MILL, JOHN STUART. 1958 [1861]. Considerations on Representative Government. New York: Liberal Arts Press. 
NORRIS, PIPPA. 2003. The Gender Gap: Old Challenges, New Approaches, in SUSAN J. Carroll (ed), Women and American politics: New Questions, New Directions. Oxford: Oxford University Press, pp. 146-70.

NORRIS, PIPPA, JONI LOVENDUSKI and ROSIE CAMPBELL. 2004. Research report: Gender and political participation. London: The Electoral Commission (UK).

PAXTON, PAMELA. 2002. Social Capital and Democracy: An Interdependent Relationship. American Sociological Review 67(2): 254-77.

PERSSON, TORSTEN and GUIDO TABELLINI. 2003. The Economic Effects of Constitutions. Cambridge, Massachusetts: MIT Press.

PHILLIPS, ANNE. 1998. Democracy and Representation: Or, Why Should it Matter Who our Representatives Are?, in Feminism and Politics. Oxford: Oxford University Press, pp. 224-40.

PITKIN, HANNA F. 1967. The Concept of Representation. Berkeley/Los Angeles: University of California Press.

POWELL, G. BINGHAM. 1986. American Voter Turnout in Comparative Perspective. American Political Science Review 80(1), 17-43.

2004. Political Representation in Comparative Politics. Annual Review of Political Science 7(1): 273-96.

PUTNAM, ROBERT D. 2000. Bowling Alone: The Collapse and Revival of American Community. New York: Simon \& Schuster.

SAPIRO, VIRGINIA and PAMELA JOHNSTON CONOVER. 1997. The Variable Gender Basis of Electoral Politics: Gender and Context in the 1992 US Election. British Journal of Political Science 27(4): 497-523.

SAWER, MARIAN, MANON TREMBLAY and LINDA J. TRIMBLE. 2006. Representing Women in Parliament: a Comparative Study. New York: Routledge.

SCHUMPETER, JOSEPH A. 1942. Capitalism, Socialism, Democracy. New York: Harper.

SNIJDERS, TOM A. B. and ROEL J. BOSKER. 1999. Multilevel Analysis: an Introduction to Basic and Advanced Multilevel Modelling. London: Sage Publications.

SWAIN, CAROL. 1993. Black Faces, Black Interests: The Representation of African Americans in Congress. Cambridge: Harvard University Press.

SWERS, MICHELE L. 2002. The Difference Women Make: the Policy Impact of Women in Congress. Chicago: University of Chicago Press.

TEACHMAN, JAY and KYLE CROWDER. 2002. „Multilevel Models in Family Research: Some Conceptual and Methodological Issues“. Journal of Marriage and Family 64(2): 280-94.

URBINATI, NADIA and MARK E. WARREN. 2008. The Concept of Representation in Contemporary Democratic Theory. Annual Review of Political Science 11(1): 387-412.

VERBA, SIDNEY and NORMAN H. NIE. 1972. Participation in America. New York: Harper \& Row.

VERBA, SIDNEY, KAY L. SCHLOZMAN and HENRY E. BRADY. 1995. Voice and Equality: Civic Voluntarism in American Politics. Cambridge: Harvard University Press.

WHITBY, KENNY. 1997. The Color of Representation: Congressional Behavior and Black Interests. Ann Arbor: University of Michigan Press. 
WILLIAMS, MELISSA S. 1998. Voice, Trust, and Memory: Marginalized Groups and the Failings of Liberal Representation. Princeton, NJ: Princeton University Press.

WOLBRECHT, CHRISTINA and DAVID E. CAMPBELL. 2007. Leading by Example: Female Members of Parliament as Political Role Models. American Journal of Political Science 51(4): 921-39.

WOLBRECHT, CHRISTINA. 2002. Female Legislators and the Women's Rights Agenda: From Feminine Mystique to Feminist Era, in Cindy S. Rosenthal (ed), Women Transforming Congress. Norman: University of Oklahoma Press, pp. 170- 97.

YOUNG, IRIS MARION. 2002. Inclusion and Democracy. Oxford: Oxford University Press. 